\title{
Antioxidant extracts of African medicinal plants induce cell cycle arrest and differentiation in B16F10 melanoma cells
}

\author{
ANGELO GISMONDI ${ }^{1}$, LORENA CANUTI ${ }^{1}$, STEFANIA IMPEI ${ }^{1}$, GABRIELE DI MARCO $^{1}$, \\ MAURICE KENZO $^{2}$, VITTORIO COLIZZI ${ }^{1}$ and ANTONELLA CANINI ${ }^{1}$ \\ ${ }^{1}$ Department of Biology, University of Rome 'Tor Vergata', I-00133 Rome, \\ Italy; ${ }^{2}$ S/C 46 P.A. de Lingang Dschange, Cameroon
}

Received April 26, 2013; Accepted June 9, 2013

DOI: 10.3892/ijo.2013.2001

\begin{abstract}
African ethnomedicine is essentially based on the traditional use of vegetal extracts. Since these natural drugs have shown health giving properties, in the present study we increased further the scientific basis supporting these data. We investigated the effects, on murine B16F10 melanoma cells, of plant extracts that were directly obtained by a Cameroon 'traditional healer'. After a preliminary study on the antioxidant functions of these compounds, already abundant in literature, Moringa oleifera Lam., Eremomastax speciosa (Hochst.) Cufod and Aframomum melegueta K. Schum extracts were individually analyzed. We performed laboratory assessments on these medicinal preparations in order to clearly demonstrate their antineoplastic features. All the treatments caused in tumor cells a great reduction in growth and proliferation rate, cell cycle arrest, increase of p53, p21 ${ }^{\mathrm{WAF} / \mathrm{Cipl}}$ and $\mathrm{p} 27^{\mathrm{Kipl}}$ protein levels and induction of differentiation. These results, on the bioactivity and the biochemical characteristics of African plant extracts, may increase the comprehension of indigenous therapeutic practices and represent the first step for the individuation of new inexpensive and natural drugs able to prevent and contrast cancer onset.
\end{abstract}

\section{Introduction}

African natives infrequently visit public health services and drugs and therapies are usually too expensive for their standard of living. Therefore, they rely heavily on ethnomedicine and ancient traditions, preserved from the past, in order to cure and prevent their pathologies $(1,2)$. In African communities, medicinal plant identification, processing and administration to patients are commonly consigned to 'traditional healers' who receive relative guidelines by their ancestors during the

Correspondence to: Professor Antonella Canini, Department of Biology, University of Rome 'Tor Vergata', Via della Ricerca Scientifica 1, I-00133, Rome, Italy

E-mail: canini@uniroma2.it

Key words: Moringa oleifera Lam., Eremomastax speciosa (Hochst.) Cufod, Aframomum melegueta K. Schum, Cameroon ethnomedicine, antineoplastic effects, B16F10 differentiation markers dreams. These folkloric approaches are essentially based on the use of plant extracts directly on wounds or as treatment by oral ingestion (3). Many studies have been performed to ascertain the scientific basis of African plant biological effects. In particular, they have demonstrated how these vegetal compounds were characterized by a great amount of secondary metabolites with antiradical power (4-6). Environmental conditions highly influence the levels and the quality of these compounds that, in nature, are synthesized only by plants, to protect themselves from biotic and abiotic factors or to facilitate their propagation (7). Since in the equatorial and tropical climates, UV exposure and temperatures are extreme, African plant phyto-complexes have been shown to be richer in antioxidant molecules than subtropical and temperate ones (8). Alkaloids, tannins, steroids, terpenoids, terpenes, flavonoids, simple phenols, phenolic acids and glycosides have been recognized as the principal metabolites whose powerful molecular activity has made African plant extracts real alternative medicines, especially, on arthritis, flu, diabetes, psoriasis, tuberculosis, ulcers, infections, asthma, hypertension, central nervous system disorders, laryngitis, liver disorders, bronchitis and also cancer $(2,9,10)$. After all, $>50 \%$ of modern drugs are composed by molecules of vegetal origin because of their inexpensive production costs, high bioactive functions and low toxicity with respect to artificial chemical substances (4). The present study was conducted with the aim to find vegetal substances able to represent efficient and alternative substitutions to the actual tumor chemotherapeutics, reported to have serious side-effects for patients (11). In this study, different plant extracts, normally used in African local tradition as natural drugs, were characterized by their free radical scavenging activity and total phenolic content. The most antioxidant ones were also evaluated for their antiproliferative and differentiative effects on the B16F10 murine melanoma cell line. The knowledge of the medicinal plant properties on biological systems and the individuation of the molecular mechanisms that they can activate are essential aspects for the identification and the development of new drugs as well as to give scientific basis to African medical culture.

\section{Materials and methods}

Plant material and extract preparations. African plant materials (Table I) were collected, by an indigenous 'traditional 
healers', in the Cameroon forests (Central Africa) and then dried, under the sun, until they were completely dehydrated. Plant extracts were obtained in the laboratory according to African tradition. Briefly, samples were ground with pestle, mortar and liquid nitrogen and then boiled in bidistilled water $(1 \mathrm{mg} / \mathrm{ml})$ for $1 \mathrm{~h}$. Extracts were filtered $(0.22 \mu \mathrm{m})$ and finally stored at $-20^{\circ} \mathrm{C}$.

Total phenolic content. Total phenolic content was assessed by Folin-Ciocalteau assay (12). Briefly, $9 \mathrm{ml}$ of $\mathrm{ddH}_{2} \mathrm{O}$ and $1 \mathrm{ml}$ of Folin-Ciocalteau reagent (Sigma-Aldrich) were added to $1 \mathrm{ml}$ of each extract. After $5 \mathrm{~min}$, the solution was supplemented with $10 \mathrm{ml}$ of $\mathrm{Na}_{2} \mathrm{CO}_{3} 7 \%(\mathrm{w} / \mathrm{v})$ and $4 \mathrm{ml}$ of $\mathrm{ddH}_{2} \mathrm{O}$, vortexed and incubated at room temperature for $1 \mathrm{~h}$ in the dark. Total phenolic concentration was detected by measuring the sample absorbance at $760 \mathrm{~nm}$ (UV-visible spectrophotometer Cary 50, Bio Varian), with respect to a caffeic acid calibration curve (20-100 mg/l). Results are expressed as $\mu \mathrm{g}$ of caffeic acid equivalents per mg of dried sample ( $\mu \mathrm{g} \mathrm{CAE} / \mathrm{mg} \mathrm{DW})$.

FRAP antiradical test. FRAP assay was performed as previously reported (13). Plant extract $(200 \mu \mathrm{l})$ was mixed with $1.8 \mathrm{ml}$ FRAP reagent $\left(10 \mathrm{mM}\right.$ TPTZ in $40 \mathrm{mM} \mathrm{HCl}, 20 \mathrm{mM} \mathrm{FeCl}_{3}$, $0.3 \mathrm{M}$ acetate buffer $\mathrm{pH} 3.6 ; 1: 1: 10 \mathrm{v} / \mathrm{v} / \mathrm{v}$ ) and placed in the dark, at $37^{\circ} \mathrm{C}$ for $10 \mathrm{~min}$. This test evaluated the capacity of natural antioxidants to reduce the colorless Fe III - tripyridyltriazine compound (Merck) to the blue-colored Fe II form, measuring sample absorbance change at $593 \mathrm{~nm}$. Ascorbic acid (AA in $\left.\mathrm{ddH}_{2} \mathrm{O}\right)$ was used to obtain a standard solution $(50-500 \mu \mathrm{M})$. Results are expressed as $\mu \mathrm{g}$ of ascorbic acid equivalents per mg of dried sample ( $\mu \mathrm{g}$ AA/mg DW).

DPPH antioxidant assay. According to Brand-Williams et al (14), plant extract antioxidant activity was measured by the determination of its scavenging property against the stable free radical 2,2-diphenyl-1-picrylhydrazyl (DPPH, Merck). In brief, the absorbance decrease, at $517 \mathrm{~nm}$, of a $100 \mu \mathrm{M}$ DPPH methanolic solution was monitored, after $30 \mathrm{~min}$ of sample addition. The antiradical effect of the extract is reported as $\mathrm{IC}_{50}$ (sample concentration causing $50 \%$ of DPPH activity reduction with respect to the control).

Cell culture, treatments, proliferation assays and microscopic observations. Highly metastatic B16F10 murine melanoma cells were grown and propagated in Dulbecco's modified Eagle's medium (D-MEM), supplemented as reported in Gismondi et al (15), under standard culture conditions (16). To study African plant antiproliferative effects, melanoma cells were seeded in 35-mm dishes and treated with vegetal extracts ( $2 \mathrm{mg}$ of plant dried weight per $\mathrm{ml}$ of cell culture media) for 24,48 and $72 \mathrm{~h}$ (control cells were treated with phosphate-buffered saline). Other treatment concentrations were also tested (data not shown). Cell proliferation and treatment cytotoxicity were evaluated by counting cells, with a Neubauer modified chamber, after trypan blue staining $(1 \%, w / v)$. In addition, cell growth, measured as function of mitochondrial activity, was analyzed by 3-(4,5-dimethylthiazol-2-yl)-2,5-diphenyltetrazolium bromide (MTT) kit (Sigma). Microscopic observations were also performed on cells by optical microscope (20X) (Nikon, TE2000-PFS).
Flow cytometry analysis. Cells were washed twice in phosphate-buffered saline and fixed for $30 \mathrm{~min}$ at $4^{\circ} \mathrm{C}$ in cold methanol:acetone (4:1) solution. Then, cells have been treated, at room temperature, for 20 min with RNase A $(100 \mu \mathrm{g} / \mu \mathrm{l})$ and for further $20 \mathrm{~min}$ with propidium iodide $(1 \mathrm{mg} / \mathrm{ml})$, and analyzed by FACSCalibur instrument (Becton-Dickinson) and the percentage of cells in the different cell cycle phases was measured by CellQuest software.

Western blotting. Cells were harvested, resuspended in RIPA lysis buffer, containing $1 \%$ protease inhibitor cocktail, and centrifuged at $13,000 \mathrm{rpm}$ for $30 \mathrm{~min}$ at $4^{\circ} \mathrm{C}$. Protein concentration was quantified by Bradford method (17), using bovine serum albumin as standard. Proteins were separated on $12 \%$ sodium dodecyl sulfate-polyacrylamide gel and transferred onto Protran nitrocellulose membrane (Schleicher and Schuell). Blots were incubated with the following primary antibodies: rabbit polyclonal anti- $\beta$-actin (Sigma), mouse monoclonal anti-p53 (Santa Cruz), mouse monoclonal anti-p27 ${ }^{\mathrm{Kip} 1}$ (BD Pharmingen), mouse monoclonal anti-p21 $1^{\text {WAF1/Cip1 }}$ (Sigma) and goat polyclonal anti-MITF (microphthalmia-associated transcription factor, Santa Cruz). Finally, primary antibodies were revealed using horseradish peroxidase-conjugated anti-rabbit or anti-mouse or anti-goat antibodies (Sigma) and an ECL chemiluminescence detection system (Pierce). Signal detection and quantification was executed, respectively, by VersaDoc Imaging System and Quantity One software (Bio-Rad).

Tyrosinase activity and melanin content. In vitro L-3,4dihydroxyphenylalanine (L-DOPA) oxidation by protein extracts was used as direct indicator of cell tyrosinase activity, as previously described (18). In summary, treated and untreated cells were resuspended in $10 \mathrm{ml}$ of lysis buffer $(50 \mathrm{mM}$ sodium phosphate buffer $\mathrm{pH} 6.8$, Triton X-100 $1 \%$ and $0.1 \mathrm{mM}$ phenylmethylsulfonyl fluoride) and frozen at $-80^{\circ} \mathrm{C}$ for $30 \mathrm{~min}$. Then, cell extracts were centrifuged at $12000 \mathrm{rpm}$ for $30 \mathrm{~min}$ at $4^{\circ} \mathrm{C}$. The supernatant $( \pm 8 \mathrm{ml})$ was mixed with $2 \mathrm{ml}$ of L-DOPA ( $2 \mathrm{mg} / \mathrm{ml}$ ) and the absorbance at $492 \mathrm{~nm}$ of the solution was monitored, after incubation for $1 \mathrm{~h}$ at $37^{\circ} \mathrm{C}$, by the UV-visible spectrophotometer, Cary 50 (Bio Varian). Intracellular melanin quantification was measured and performed as suggested by Lotan and Lotan (19). Briefly, cells were harvested and lysed (Tris-HCl $50 \mathrm{mM}$ pH 7.5, EDTA $2 \mathrm{mM}, \mathrm{NaCl} 150 \mathrm{mM}$, Triton X-100 1\%, protease inhibitor $1 \%$ ). Then samples were sonicated for $30 \mathrm{sec}$ and centrifuged at $1400 \mathrm{rpm}$ for $5 \mathrm{~min}$. The supernatant was used for sample protein quantization (17). The pellet was washed twice with $1 \mathrm{ml}$ of ethanol:diethyl ether (1:1) and finally resuspended in $\mathrm{NH}_{4} \mathrm{OH} 1 \mathrm{M}$ at $37^{\circ} \mathrm{C}$ until it was completely dissolved. The melanin amount in the solution was determined by analyzing the absorbance value at $475 \mathrm{~nm}$ (UV-visible spectrophotometer Cary 50, Bio Varian). Results are expressed as $\mu \mathrm{g}$ melanin per mg of cell proteins.

Statistical analysis. All experiments were repeated in triplicate and the relative results are shown as the mean \pm standard error of the mean (SEM) of the three independent measurements. Analysis of variance was conducted using one-way ANOVA test with SPSS (ver.19 ita) for Microsoft and the means were compared by Duncan tests. All p-values were $<0.05$ versus vehicle control-treated cells. 
Table I. African plant extracts.

Source

Section of the plant

CODE

Moringa oleifera Lam. - (Central region)

Hibiscus cannabinus L.

\begin{tabular}{ll} 
Leaves & MOC \\
Leaves & HC \\
Leaves & MC \\
Root & ZO \\
Cortex & PJ \\
Cortex & EC \\
Leaves & ES \\
Leaves & MN \\
Root & MNR \\
Cortex & MNC \\
Flowers & MNF \\
Seeds & MNS \\
Seeds & AM \\
Seeds & AP \\
\hline
\end{tabular}

Mormodica charantia L.

Zingiber officinale Roscoe

Pausinystalia johimbe (K. Schum.) Pierre ex Beille

Enantia chlorantha Oliv.

Eremomastax speciosa (Hochst.) Cufod.

Moringa oleifera Lam. - (North region)

Moringa oleifera Lam. - (North region)

Moringa oleifera Lam. - (North region)

Moringa oleifera Lam. - (North region)

Moringa oleifera Lam. - (North region)

Aframomum melegueta K. Schum.

Aframomum pruinosum Gagnep.

Description of African plant extracts used in this study: scientific name of the source, section of the plant which was extracted and sample contraction name (CODE).

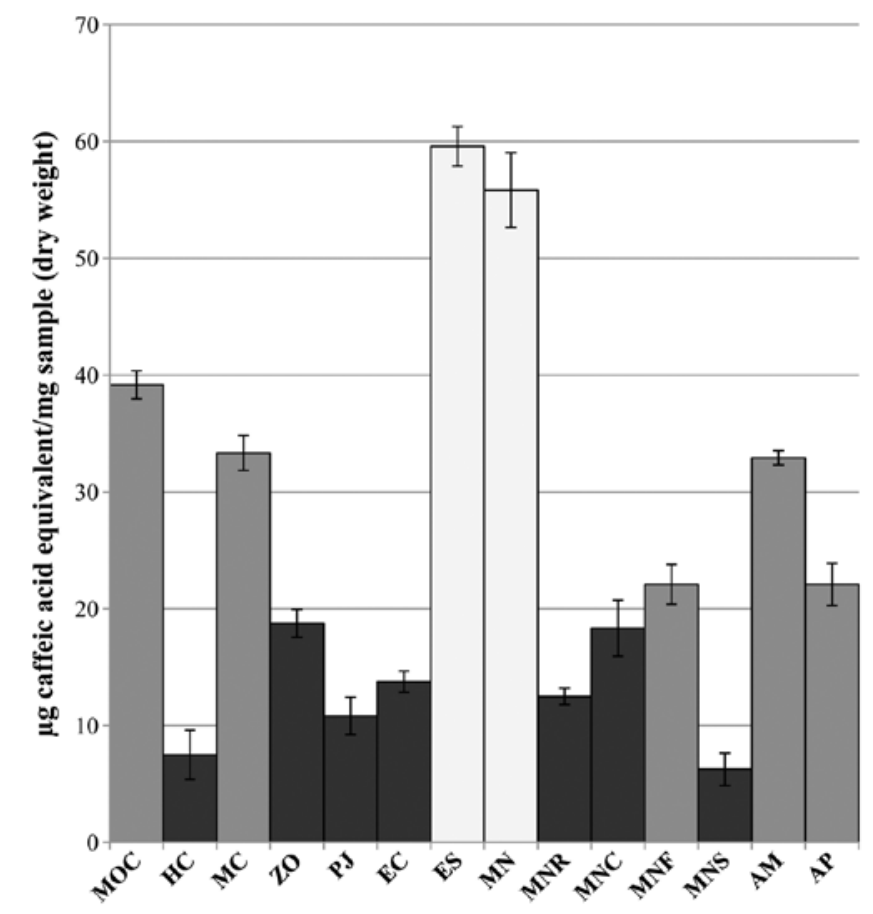

African plant extracts

Figure 1. Phenolic secondary metabolites. Total phenolic content of each African plant extract (Table I) are reported as $\mu \mathrm{g}$ of caffeic acid equivalent per mg of dry weight sample ( $\mu \mathrm{g}$ CAE/mg DW). Samples showing values $>40 \mu \mathrm{g} \mathrm{CAE} / \mathrm{mg}$ DW are indicated in light grey. Solutions that revealed aromatic secondary metabolites between 20 and $40 \mu \mathrm{g} \mathrm{CAE} / \mathrm{mg}$ DW are represented in dark grey whilst in black only specimens $<20 \mu \mathrm{g} \mathrm{CAE} / \mathrm{mg}$ DW. Data are reported as the mean of three different experiments \pm SEM.

\section{Results}

Secondary metabolites and antioxidant properties. Fourteen African plants (Table I) were processed and subjected to aqueous extraction, as described in Materials and methods. The amount of phenolic compounds was measured in each extract by a spectrophotometric analysis (Fig. 1). ES, MN, MOC, MC and AM samples showed the highest aromatic secondary metabolite contents, respectively, 59.58, 55.83, 39.17, 33.33 and $32.92 \mu \mathrm{g} \mathrm{CAE} / \mathrm{mg}$ DW. FRAP and DPPH assays were performed in order to determine the antiradical power of Cameroon plant extracts. The FRAP test (Fig. 2) allowed us to separate samples in three principal clusters, according to their antioxidant activity: the first group (including $\mathrm{HC}, \mathrm{PJ}$, EC, MNR, MNF, MNS and AP samples) revealed a radical scavenging property $<5 \mu \mathrm{g} \mathrm{AA} / \mathrm{mg} \mathrm{DW}$; the second cluster, made up of $\mathrm{MC}, \mathrm{ZO}$ and $\mathrm{MNC}$ specimens, evidenced intermediate values (between 5 and $10 \mu \mathrm{g} \mathrm{AA} / \mathrm{mg}$ DW) whilst the best antioxidant extracts (MOC, ES, MN and AM) exhibited a reducing activity $>10 \mu \mathrm{g} \mathrm{AA} / \mathrm{mg}$ DW. In DPPH assay (Fig. 3), MOC, MC, MN, ES, MNC, MNF and AM extracts were identified as the strongest antiradical solutions. In particular, they respectively, presented an $\mathrm{IC}_{50}$ value of $0.94,0.80,0.99,0.36$, $0.77,0.61$ and $0.55 \mu \mathrm{g}$ extract per $\mathrm{ml}$. In conclusion, in vitro tests showed MN, ES and AM were the most antioxidant samples.

Effects on cell growth and proliferation. B16F10 murine melanoma cells were treated for 24,48 and $72 \mathrm{~h}$ with $2 \mathrm{mg} / \mathrm{ml}$ of MN, ES and AM extracts in order to analyze their effects on cell proliferation (Fig. 4). Proliferative tests were also performed with other treatment concentrations but data are not shown in this study because of irrelevance or the excessive effects. Cells incubated for $24 \mathrm{~h}$ with African samples did not show significant changes in cell growth, with respect to the control (CNT). On the other hand, treatments with MN, ES and $\mathrm{AM}$ for $48 \mathrm{~h}$ induced a reduction of cell proliferation, compared to control cells, of $\sim 16,32$ and $39 \%$, respectively. After $72 \mathrm{~h}$ of incubation, plant extracts caused the decrease of the number of cells of 42 (MN), 47 (ES) and 61\% (AM), 


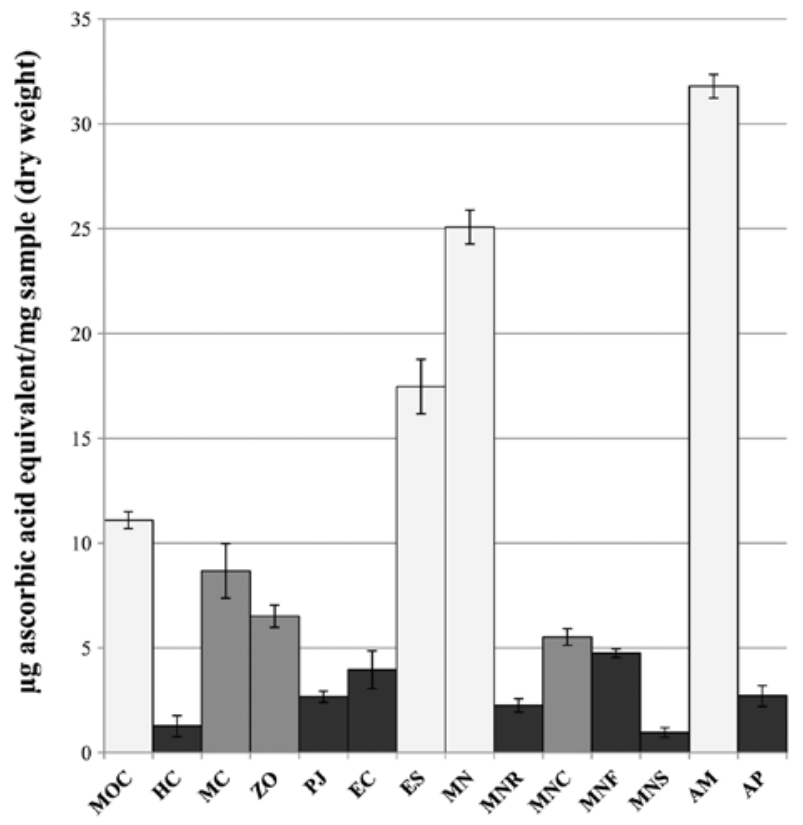

African plant extracts

Figure 2. FRAP assay. Results obtained in FRAP test are shown as $\mu \mathrm{g}$ ascorbic acid equivalent per mg dry weight sample ( $\mu \mathrm{g} \mathrm{AA} / \mathrm{mg} \mathrm{DW})$. In light grey are illustrated samples presenting antiradical power $>10 \mu \mathrm{g} \mathrm{AA} / \mathrm{mg} \mathrm{DW}$. Extracts with an intermediate antioxidant power (between 10 and $5 \mu \mathrm{g} \mathrm{AA} /$ mg DW) are represented by dark grey columns and in black the less reducing African preparations ( $<5 \mu \mathrm{g} \mathrm{AA} / \mathrm{mg} \mathrm{DW})$. Each value represents the mean of three different determinations \pm SEM.

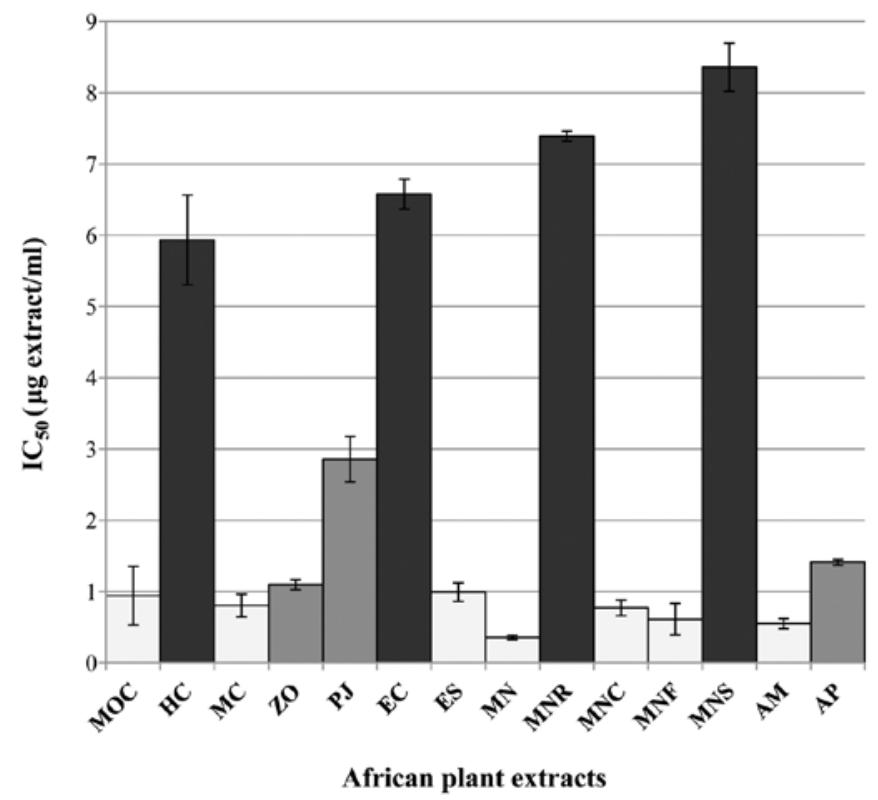

Figure 3. DPPH test. DPPH assay measurements as $\mathrm{IC}_{50}(\mu \mathrm{g}$ extract $/ \mathrm{ml})$. The most free-radical scavenging extracts $\left(\mathrm{IC}_{50}<1 \mu \mathrm{g}\right.$ extract $\left./ \mathrm{ml}\right)$ are indicated as light grey. The less antioxidant samples are reported as dark grey columns $\left(\mathrm{IC}_{50}\right.$ between 1 and $3 \mu \mathrm{g}$ extract $\left./ \mathrm{ml}\right)$ and black $\left(\mathrm{IC}_{50}>3 \mu \mathrm{g}\right.$ extract $\left./ \mathrm{ml}\right)$. Data are reported as the mean of three different experiments \pm SEM.

with respect to the control. To determine if natural solutions could be toxic for cells, trypan blue exclusion test was also performed. As reported in Table II, treatments for $24 \mathrm{~h}$ did

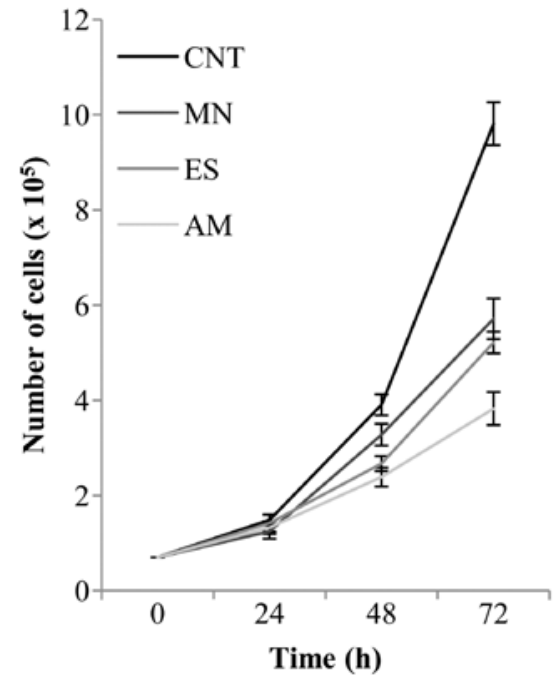

Figure 4. Antiproliferative study. Proliferation curve of B16-F10 cells treated with $2 \mathrm{mg} / \mathrm{ml}$ of MN (dark grey), ES (grey) and AM (dark) for 24, 48 and $72 \mathrm{~h}$. Control cells (CNT, black) were incubated, for the same time periods, with equivalent volume of phosphate-buffered saline. Results are expressed as number of cells $\left(\times 10^{5}\right)$. Data are reported as the mean of three different experiments \pm SEM.

Table II. Cytotoxicity percentage of African extracts on B16F10 cells.

\begin{tabular}{lcrrr}
\hline $\begin{array}{l}\text { Treatment } \\
\text { (hours) }\end{array}$ & CNT (\%) & MN (\%) & ES (\%) & AM (\%) \\
\hline 24 & 5.3 & 7.1 & 5.7 & 6.5 \\
48 & 4.1 & 16.5 & 9.5 & 9.8 \\
72 & 4.4 & 26.3 & 10.8 & 11.2 \\
\hline
\end{tabular}

B16F10 melanoma cell toxicity, revealed by trypan blue exclusion test, after treatment with African plant extracts (MC, ES, AM) for 24, 48 and $72 \mathrm{~h}$. Control cells (CNT) were treated for the same time periods with an equivalent volume of phosphate-buffered saline.

not cause any cell injury: in all cases, toxicity was $<2 \%$ with respect to control cells. After $48 \mathrm{~h}$, ES and AM solutions still showed slight cytotoxicity $(<6 \%)$ whilst MN extract was $\sim 12 \%$, compared to control cells. Cells remained highly viable also after $72 \mathrm{~h}$ of contact with ES and AM extracts (only 7\% of toxicity was detected); in contrast, $\mathrm{MN}$ treatment induced the death of $\sim 22 \%$ of cells, with respect to the control. Cell proliferation, after treatment with Cameroon plant extracts for $72 \mathrm{~h}$, was further monitored by MTT assay (Fig. 5). MN, ES and AM treatments produced a decrease of cell growth of $42.7,50.9$ and $39.4 \%$, respectively, compared to control cells.

Analysis of the cell cycle and related proteins. In order to verify if the previous reduction of B16F10 cell proliferation was associated with cell cycle modifications, FACS analysis was carried out. After treatment for $72 \mathrm{~h}$ with the different African preparations, very contrasting cell cycle profiles were revealed (Fig. 6), compared to the control (CNT). In particular, the amount of apoptotic cells, that was minimal in the control 


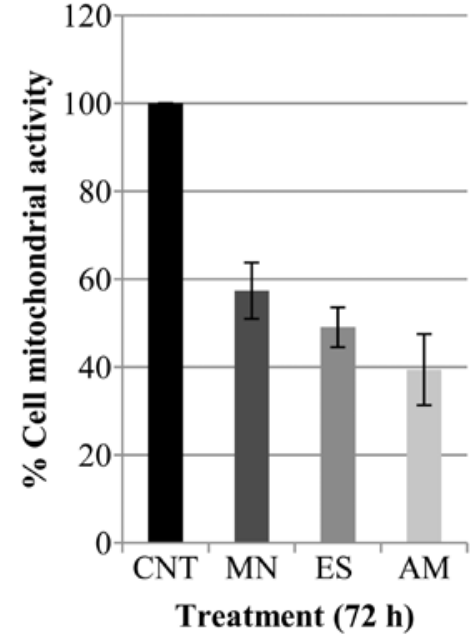

Figure 5. Cell growth evaluation. Cell mitochondrial activity measurement of B16F10 treated with $2 \mathrm{mg} / \mathrm{ml}$ of $\mathrm{MN}$ (dark grey), ES (grey) and AM (dark) for $72 \mathrm{~h}$. Results were expressed as percentage with respect to the control (CNT, black) that was treated, for the same time perods as phosphate-buffered saline. Each value represents the mean of three different determinations \pm SEM.

(2.6\%), increased after MN treatment (21.2\%) with respect to ES and AM, whose sub-G1 events were only 3.8 and $4.9 \%$, respectively. As indicated in Fig. 7, with respect to the control, MN treatment produced an increase in G2/M phase (10.9\%), ES solution induced an accumulation of cells (13.4\%) between the $\mathrm{S}$ and $\mathrm{G} 2 / \mathrm{M}$ peaks whilst AM extract clearly caused the arrest of the cell cycle in G1 phase (13.9\%). Protein extraction was performed on B16F10 cells and the principal cell cycle regulators were detected by western blotting (Fig. 8). MN, ES and AM solutions enhanced p53 levels 50.8, 28.8 and 40.1\%, in this order, with respect to the control. Similarly, $\mathrm{p}^{\mathrm{WAF}}{ }^{\mathrm{WA} / \mathrm{Cip} 1}$ content was highly increased following the treatments ( $>300 \%$ of the control). As a final point, $\mathrm{p} 27^{\mathrm{Kipl}}$ amount was investigated in cell protein extracts: the levels augmented of 29 and 25\%, respectively, with ES and AM extracts and, remarkably, of $143 \%$ following MN treatment, with respect to control cells.

Differentiation induction. Differentiative properties of Cameroon plant extracts on B16F10 cell line, were also checked. After treatment for $72 \mathrm{~h}$ with MN, ES and AM extracts, with respect to the control, cells evidenced great morphological changes and decrease of cell density. Optical microscope images (Fig. 9) clearly showed how treated cells (especially MN

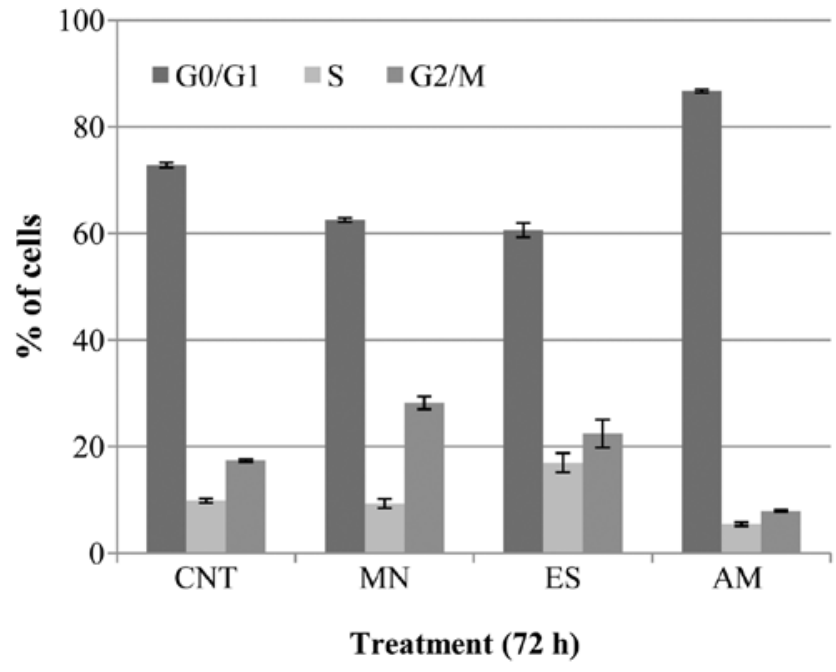

Figure 7. Cell cycle analysis. After treatment for $72 \mathrm{~h}$ with the different African plant extracts, as described in Materials and methods, cell cycle analysis was performed by FACS. Percentages of cells in G0/G1, S and G2/M phases are shown in this figure for each sample (MN, ES and AM) and control (CNT)

and ES) had developed cytoplasmic dendritic protrusions and acquired a star shape. Melanin amount (Fig. 10) and tyrosinase activity (Fig. 11) were studied in cells after exposure to African preparations for $72 \mathrm{~h}$. With respect to control cells, MN, ES and AM treatments, respectively, increased cellular pigment levels of 33.9, 68 and 59\% and enzyme activity of 1.6-, 2.2- and 2.1-fold. In addition, MITF protein was detected in MN, ES and AM protein samples: respectively, western blot analysis revealed an increase of the transcription factor 1.6-, 1.8- and 1.9-fold, compared to control cells, as shown in Fig. 12).

\section{Discussion}

The detection and characterization of plant compounds have recently attracted research attention because of their impact on human health and economy. The great biological activity of these molecules and the low costs of their natural synthesis are largely substituting the production of the modern synthetic drugs (4). By contrast, in Africa the use of plant extracts as medicine is an actual and very common practice that hails from ancient rituals. Nevertheless, Africans have often attributed and associated plant therapeutic features to spiritualist agents (20). The aim of this study was to investigate the health
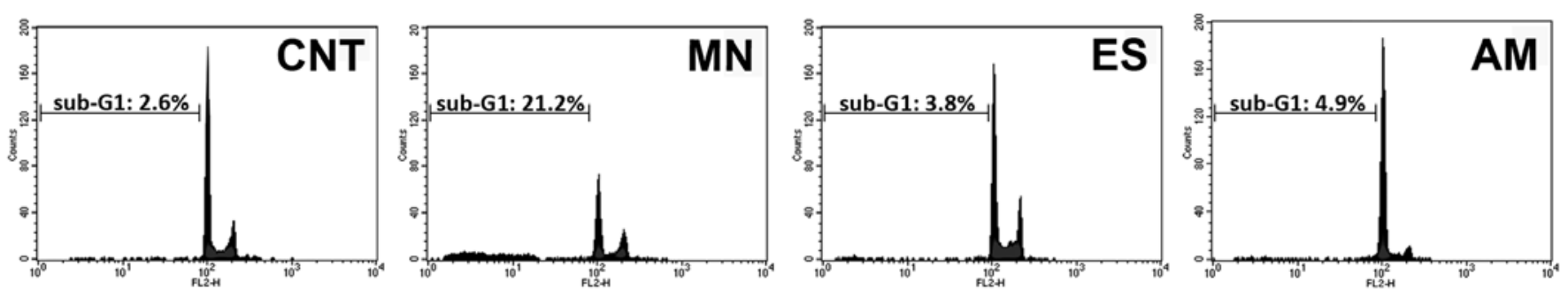

Figure 6. FACS profiles. Histograms of cell cycle distribution of samples. Cells were exposed, for $72 \mathrm{~h}$, to $2 \mathrm{mg} / \mathrm{ml}$ of MN, ES and AM (phosphate-buffered saline for the control, CNT), stained with propidium iodide solution and 10,000 events per assay were then analysed by flow cytometry. The amount of apoptotic nuclei, detected in the sub-G1 area, are reported as percentage. 
a
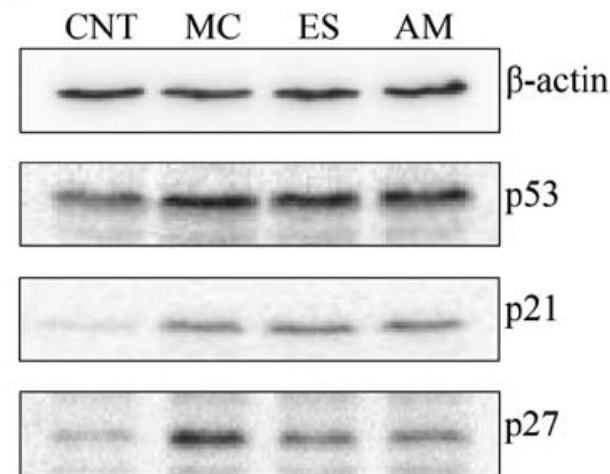

b

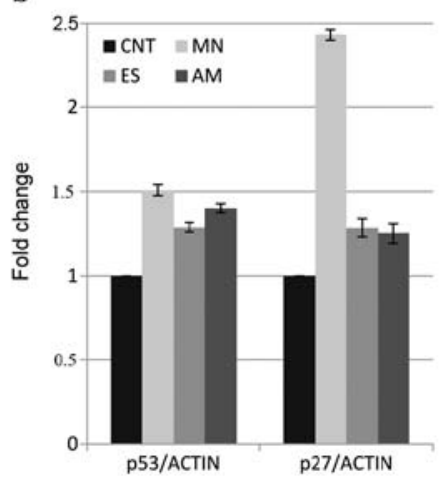

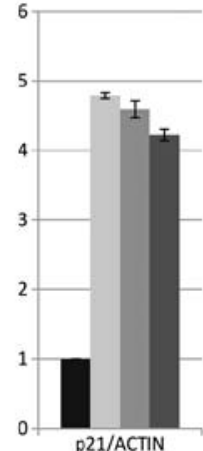

Figure 8. Detection of p53, p2 $1^{\mathrm{WAF} 1 / \mathrm{Cip} 1}$ and $\mathrm{p} 27^{\mathrm{Kip} 1}$. Immunoblot analysis of the p53, p21 $1^{\mathrm{WAF} 1 / \mathrm{Cip} 1}$ and $\mathrm{p} 27^{\mathrm{Kip} 1}$ protein levels was carried out. Representative immunoblots of the three independent experiments, with similar results, are shown (a). $\beta$-actin was employed as a loading control. Results are expressed as fold changes with respect to the control values (b). Data are reported as the mean of three different experiments \pm SEM.

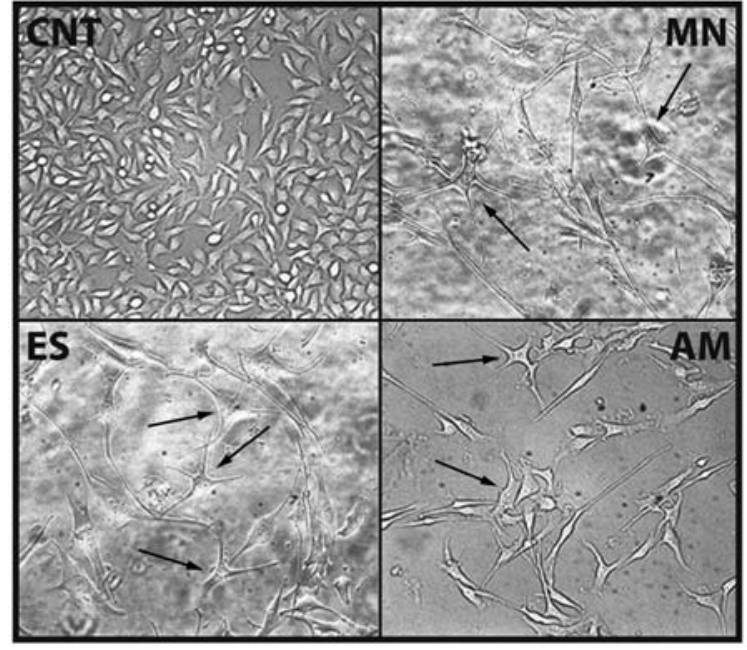

Figure 9. Cell microscope observations. Images of B16F10 cells, obtained by a light microscope (x20), after treatment with $2 \mathrm{mg} / \mathrm{ml}$ of MN, ES and AM for $72 \mathrm{~h}$. The reduction in cell density and the development of cytoplasmic protrusions were clearly evidenced with respect to control cells (CNT), treated only with phosphate-buffered saline.

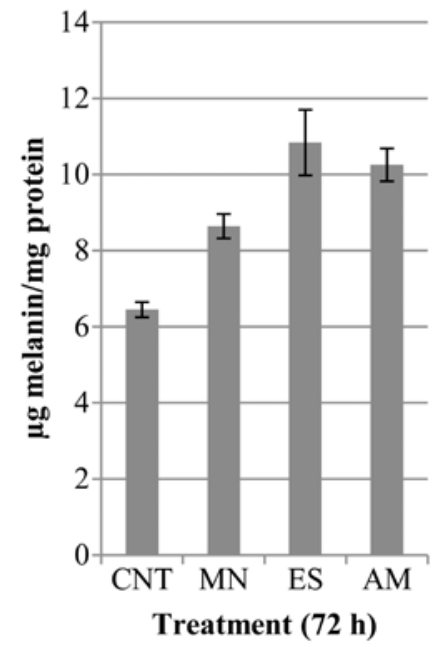

Figure 10. Melanin amount. Effect of the treatments (CNT, MN, ES and AM) for $72 \mathrm{~h}$ on melanin content in B16-F10 melanoma cells. Data are indicated as $\mu \mathrm{g}$ of melanin per mg of proteins, for each sample. Results are reported as the mean of three different experiments \pm SEM

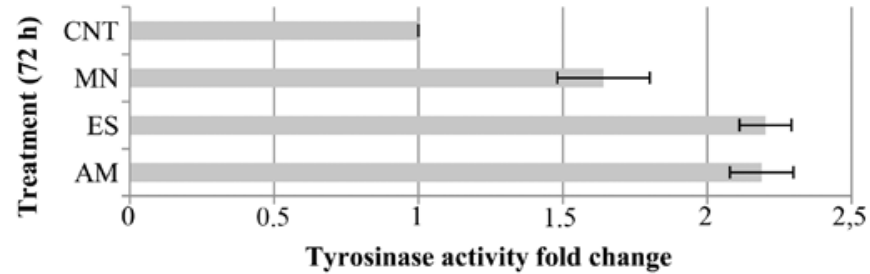

Figure 11. Tyrosinase function. Determination of tyrosinase activity, a differentiation marker, in MN, ES and AM treated murine B16-F10 melanoma cells. Data are reported as fold changes with respect to the control (CNT) and represent the mean of three different experiments \pm SEM.

giving properties of African plant extracts (Table I), collected from Cameroon forests, that indigenous peoples daily employ in ethnomedicine. We planned to identify the antineoplastic effects of plant sample preparations on murine cancer cells. We decided to carry out plant extracts by using hot water, even if a more organic and less polar solvent would have had a greater capacity in the extraction of plant compounds (21), in order to obtain solutions that would be similar to the vegetal preparations used by African natives. Oxidative and reducing processes are essential for cell survival but when their equilibrium is imbalanced cellular stability is altered. In particular, high levels of reactive oxygen species (ROS) have been demonstrated able to induce cell structural damage and apoptosis $(22,23)$. Plant molecules, in general, have been recognized as strong antiradical compounds able to reduce cell oxidation: therefore, a correct diet, rich in vegetables and fruits, is considered an important factor for the prevention of several diseases, including cancer, by its ability to prevent and to rescue oxidative stress (24). Therefore, we begun this research by analyzing sample antioxidant activity. Secondary metabolites in plants can approximately range between 6.8 and $32.1 \mu \mathrm{g} \mathrm{CAE} / \mathrm{mg}$ DW, although it highly depends on plant environmental and physiological conditions (25). In this study, ES and MN extracts were demonstrated to possess a total phenolic content that abundantly exceeded these values (Fig. 1). Moreover, the same plant species and AM sample also showed the strongest antioxidant properties (Figs. 2 and 3), with respect to the other African extracts and correlated litera- 


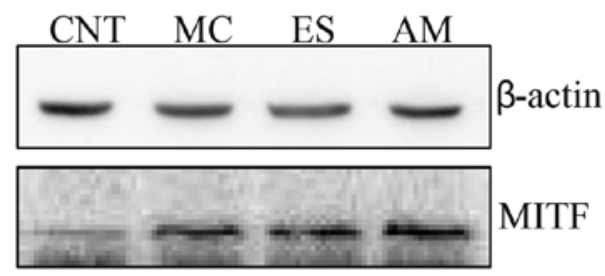

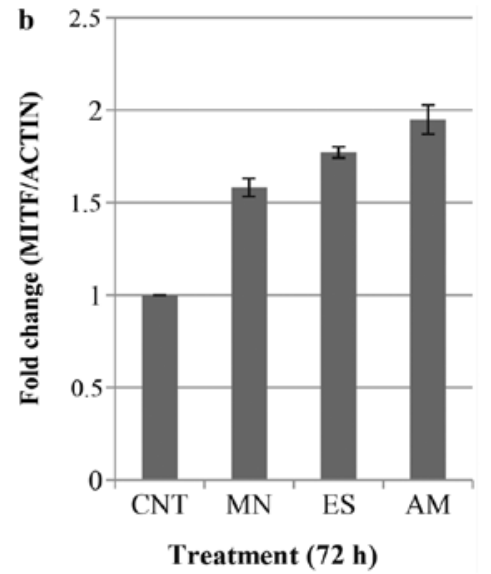

Figure 12. MITF level. Western blotting showing MITF protein amount. An example of one of the three independent blots, that were performed exhibiting similar results, is reported (a). $\beta$-actin was used as a loading control. Results are reported as fold changes with respect to the control sample (b). Each value represents the mean of three different determinations \pm SEM.

ture data (26-28). Another important result was that M. oleifera (North region) leaves (MN) showed the most conspicuous quantity of free radical scavenging molecules with respect to the other plant districts of the same species (MNR, MNF, MNC and MNS samples). Over the past few decades, African plant features have been largely described in scientific publications $(6,9,10)$. In other reports, $M$. oleifera has been demonstrated a rich source of ascorbic acid, oestrogenic substances, iron, calcium, phosphorus, copper, vitamins, riboflavin, nicotinic acid, folic acid, pyridoxine, $\beta$-carotene, proteins and essential amino acids (29). Its extract also exhibit antibacterial, antifungal, antihypertensive, diuretic, hepatoprotective and cholesterol lowering activities $(30,31)$. Anticancer properties of this plant have been studied both in vivo on mice and more rarely in vitro on tumor cell lines $(32,33)$. On the other hand, E. speciosa and A. melegueta species have shown antifungal, anti-inflammatory, antibacterical, gastro-protective and fertilizing effects (34-36). However, no report has been clearly focused on their antitumoral properties. Therefore, special core of this study was the investigation of the effects and the molecular mechanisms that MN, ES and AM preparations could activate and/or regulate on the melanoma B16-F10 murine cell line. We evaluated the effect of these solutions on cell viability. Trypan blue test (Table II) showed that ES and AM extracts had no toxic effects on cells, as expected because of their simple processing in water and the naturalness of their contents. Instead, surprisingly, $\mathrm{MN}$ treatment caused the death of $\sim 22 \%$ of total cells, with respect to the control. Different plant extracts contain diverse metabolite profiles (7) and, probably, MN phyto-complex presented one or more compounds, absent in ES and AM, able to induce cell instability and death (33). However, after treatment for different times with MN, ES and AM extracts, cell proliferation (Fig. 4) and growth (Fig. 5) were greatly reduced. Cell cycle alteration and apoptosis inhibition are the principal characteristics of cancer cells (37); therefore, FACS analysis was performed to clarify if treated cells could undergo cell cycle modifications in order to justify the decrease of cell proliferation. As anticipated, samples produced different effects on the cell cycle:
MN induced a G2/M phase arrest, ES associated the block of cells both in $\mathrm{S}$ phase and in $\mathrm{G} 2 / \mathrm{M}$ and finally AM caused a G0-G1 stop (Fig. 7). Moreover, a large amount of apoptotic nuclei, detected by propidium iodide staining, was only observed in the sub-G1 area of MN specimen (Fig. 6); it confirmed further the results obtained in the exclusion test (Table II). It is well-known that p53 is a tumor suppressor protein: $\sim 80 \%$ of cancer cells are characterized by alterations in p53 gene or activity. When DNA damage occurs in cells, p53 is activated and accumulated in the nucleus where it promotes the transcription of different genes involved in DNA repair, cell growth arrest and apoptosis thus preventing cancinogenesis (38). Of the p53 targets, the CIP/KIP p21 and p27 cyclin-dependent kinase (CDK) inhibitors are the most investigated genes because of their ability to induce cell cycle arrest (39). The study of these protein markers was complementary to cytofluorimetric analysis and essential for clarifying the basal molecular mechanisms that might have induced the inhibition of the proliferation. We demonstrated that all treatments (MN, ES and AM) enhanced p53, p21 ${ }^{\mathrm{WAF} 1 /}$ Cip1 and $\mathrm{p} 27^{\mathrm{Kip} 1}$ protein levels in B16F10 melanoma cells (Fig. 8). Probably, the African plant extracts produced in cells induction of p53 that consequently stimulated the $\mathrm{p} 21^{\mathrm{WAF} 1 / \mathrm{Cip} 1}$ and $\mathrm{p} 27^{\mathrm{Kip} 1}$-dependent cell cycle arrest. Different cell cycle profiles (Fig. 7) could be explained by a different activity of $\mathrm{p} 21^{\mathrm{WAF} 1 / \mathrm{Cip} 1}$ and $\mathrm{p} 27^{\mathrm{Kip} 1}$ in melanoma cells. Coqueret (39) reported that these two proteins inhibit all CDK complexes, without a specific restriction for a particular cell phase. Therefore, an increase in $\mathrm{p} 21^{\mathrm{WAF} 1 / \mathrm{Cip} 1}$ or $\mathrm{p} 27^{\mathrm{Kip} 1}$ can be easily associated with both G0-G1 and S or G2-M phase block (40-42). A remarkable increase of $\mathrm{p} 27^{\mathrm{Kip} 1}$ level was detected in an MN sample (Fig. 8). The overexpression of this protein might be the reason, or the consequence, of the activation of an apoptotic pathway in cells; in fact, it is proved that a great $\mathrm{p} 27^{\mathrm{Kipl}}$ increment triggers apoptosis in different cell lines $(43,44)$. This preliminary hypothesis that should be further confirmed by other experiments, would explain the large amount of dead cells detected only after treatment with MN (Figs. 6 and 7). Alteration in cell morphology, with the development of dendritic protrusions, reduction of proliferation and 
activation of melanogenesis have been considered specific indicators of differentiation for melanoma cell lines $(45,46)$. The induction of this process in B16F10, after treatment with Cameroon extracts, was firstly and clearly suggested by cell acquisition of typical cytoplasmic extensions (Fig. 9). In literature, it has been well documented that p53 is a transcriptional regulator in melanogenesis. Via $\mathrm{p} 21^{\mathrm{WAF} 1 / \mathrm{Cip} 1}$, it positively regulates the promoter of microphthalmia-associated transcription factor (MITF). The latter plays a central role in the expression of melanocyte-specific genes such as tyrosinase, the key enzyme of melanin synthesis (47). Melanin production (Fig. 10), tyrosinase activity (Fig. 11) and MITF levels (Fig. 12) were highly enhanced in all samples. These results rigorously and scientifically confirmed the antioxidant, antiproliferative and differentiative effects of the MN, ES and AM extracts that commonly Cameroon indigenous people adopt as food sources of medicinal compounds. By merging the knowledge of African tradition and laboratory evidences it might identify new nutraceutical products able to improve human health and to prevent cancer.

\section{References}

1. Steenkamp V, Mathivha E, Gouws MC and van Rensburg CEJ: Studies on antibacterial, antioxidant and fibroblast growth stimulation of wound healing remedies from South Africa. J Ethnopharmacol 95: 353-357, 2004.

2. Ojewole JAO: Antinociceptive, anti-inflammatory and antidiabetic properties of Hypoxis hemerocallidea Fisch. \& C.A Mey. (Hypoxidaceae) corm ['African Potato'] aqueous extract in mice and rats. J Ethnopharmacol 103: 126-134, 2006.

3. Soladoye MO, Amusa NA, Raji-Esan SO, Chukwuma EC and Taiwo AA: Ethnobotanical survey of anti-cancer plants in Ogun State, Nigeria. Ann Biol Res 1: 261-273, 2010.

4. Farombi OE: African indigenous plants with chemotherapeutic potentials and biotechnological approach to the production of bioactive prophylactic agents. Afr J Biotechnol 2: 662-671, 2003.

5. Scott G, Springfield EP and Coldrey N: A pharmacognostical study of 26 South African plant species used as traditional medicines. Pharm Biol 42: 186-213, 2004.

6. Atawodi SE: Antioxidant potential of African medicinal plants. Afr J Biotechnol 4: 128-133, 2005.

7. Manach C, Scalbert A, Morand C, Remesy C and Jimenez L: Polyphenols: food sources and bioavailability. Am J Clin Nutr 79: 727-747, 2004.

8. Abegaz BM, Ngadjui BT, Dango E and Bezabith MT: Chemistry of the genus Dorstenia psiurus. Curr Org Chem 4: 107-109, 2000

9. Edeoga HO, Okwu DE and Mbaebie BO: Phytochemical constituents of some Nigerian medicinal plants. Afr J Biotechnol 4: 685-688, 2005.

10. Jiofack T, Fokunang C, Guedje N, Kemeuze V, Fongnzossie E, Nkongmeneck BA, Mapongmetsem PM and Tsabang N: Ethnobotanical uses of some plants of two ethnoecological regions of Cameroon. AJPP 3: 664-684, 2009.

11. Steenkamp V and Gouws MC: Cytotoxicity of six South African medicinal plant extracts used in the treatment of cancer. S Afr J Bot 72: 630-633, 2006.

12. Singleton VL and Rossi JJA: Colorimetry of total phenolics with phosphomolybdic-phosphotungstic acid reagents. Am J Enol Viticul 16: 144-158, 1965.

13. Benzie IFF and Strain JJ: The ferric reducing ability of plasma (FRAP) as a measure of antioxidant power: the FRAP assay. Anal Biochem 239: 70-76, 1996.

14. Brand-Williams W, Cuvelier ME and Berset C: Use of a free radical method to evaluate antioxidant activity. Food Sci Technol 28: 25-30, 1995 .

15. Gismondi A, Serio M, Canuti L and Canini A: Biochemical, antioxidant and antineoplastic properties of Italian saffron (Crocus sativus L.). AJPS 3: 1573-1580, 2012.

16. Fidler IJ: Selection of successive tumor cell lines for metastasis Nat New Biol 242: 148-149, 1973.
17. Bradford MM: A rapid and sensitive method for the quantitation of microgram quantities of protein utilizing the principle of protein-dye binding. Anal Biochem 72: 248-254, 1976.

18. Gismondi A, Lentini A, Tabolacci C, Provenzano B and Beninati S: Transglutaminase-dependent antiproliferative and differentiative properties of nimesulide on B16-F10 mouse melanoma cells. Amino Acids 38: 257-262, 2010.

19. Lotan R and Lotan D: Stimulation of melanogenesis in a human melanoma cell by retinoids. Cancer Res 40: 3345-3350, 1980.

20. Ndenecho EN: Herbalism and resources for the development of ethnopharmacology in Mount Cameroon region. AJPP 3: 78-86, 2009.

21. Anoosh E, Fathemeh S, Eradatmand AD and Alireza H: Antioxidant activity of methanolic and aqueous extract of Stachys inflate. Adv Environ Biol 5: 1256, 2011.

22. Sengul M, Yildiz H, Gungor N, Cetin B, Eser Z and Ercisli S: Total phenolic content, antioxidant and antimicrobial activities of some medicinal plants. Pakistan J Pharm Sci 22: 102-106, 2009.

23. Ho SC and Chang PW: Inhibitory effects of several spices on inflammation caused by advanced glycation end products. AJPS 3: 995-1002, 2012.

24. Pan MH and Ho CT: Chemopreventive effects of natural dietary compounds on cancer development. Chem Soc Rev 37: 2258-2574, 2008

25. Bajpai M, Mishra A and Prakash D: Antioxidant and free radical scavenging activities of some leafy vegetables. Int J Food Sci Nutr 56: 473-481, 2005.

26. Siddhuraju P and Becker K: Antioxidant properties of various solvent extracts of total phenolic constituents from three different agroclimatic origins of drumstick tree (Moringa oleifera Lam.) leaves. J Agr Food Chem 51: 2144-2155, 2003.

27. Sreelatha S and Padma PR: Antioxidant activity and total phenolic content of Moringa oleifera leaves in two stages of maturity. Plant Food Hum Nutr 64: 303-311, 2009.

28. Moyo B, Oyedemi S, Masika PJ and Muchenje V: Polyphenolic content and antioxidant properties of Moringa oleifera leaf extracts and enzymatic activity of liver from goats supplemented with Moringa oleifera leaves/sunflower seed cake. Meat Sci 91: 441-447, 2012.

29. Ferreira PMP, Farias DF, Oliveira JT de A and Carvalho Ade FU: Moring a oleifera: bioactive compounds and nutritional potential. Revista de Nutrição - Campinas 21: 431-437, 2008.

30. Anwar F, Latif S, Ashraf M and Gilani AH: Moringa oleifera: a food plant with multiple medicinal uses. Phytother Res 21: 17-25, 2007.

31. Chumarka P, Khunawat P, Sanvarinda Y, Phornchirasilp S, Morales NP, Phivthongngam L, Ratanachamnong P, Srisawat S and Pongrapeeporn KS: The in vitro and ex vivo antioxidant properties, hypolipidaemic and antiatherosclerotic activities of water extract of Moringa oleifera Lam. leaves. J Ethnopharmacol 116: 439-446, 2008.

32. Paliwal R, Sharma V, Pracheta A, Sharma S, Yadav S and Sharma S: Anti-nephrotoxic effect of administration of Moringa oleifera Lam in amelioration of DMBA-induced renal carcinogenesis in Swiss albino mice. Biol Med Special Issue 3: 27-35, 2011.

33. Sreelatha S, Jeyachitra S and Padma PR: Antiproliferation and induction of apoptosis by Moringa oleifera leaf extract on human cancer cells. Food Chem Toxicol 49: 1270-1275, 2011.

34. Doherty VF, Olaniran OO and Kanife UC: Antimicrobial activities of Aframomum Melegueta (Alligator pepper). Int J Biol 2: 126-131, 2010.

35. Nwozo SO and Oyinloye BE: Hepatoprotective effect of aqueous extract of Aframomum melegueta on ethanol-induced toxicity in rats. Acta Biochim Pol 58: 355-358, 2011.

36. Telefoa PB, Lienoua LL, Yemelea MD, Lemfacka MC, Mouokeua C, Gokaa CS, Tagnea SR and Moundipab FP: Ethnopharmacological survey of plants used for the treatment of female infertility in Baham, Cameroon. J Ethnopharmacol 136: 178-187, 2011.

37. Surh YJ: Cancer chemoprevention with dietary phytochemicals. Nat Rev Cancer 3: 768-780, 2003.

38. Pitchakarn P, Suzuki S, Ogawa K, Pompimon W, Takahashi S, Asamoto M, Limtrakul P and Shirai T: Induction of G1 arrest and apoptosis in androgen-dependent human prostate cancer by Kuguacin J, a triterpenoid from Momordica charantia leaf. Cancer Lett 306: 142-150, 2011.

39. Coqueret O: New roles for p21 and p27 cell-cycle inhibitors: a function for each cell compartment? Trends Cell Biol 13: 65-70, 2003. 
40. Dozio E, Ruscica M, Passafaro L, Dogliotti G, Steffani L, Pagani A, Demartini G, Esposti D, Fraschini F and Magni P: The natural antioxidant alpha-lipoic acid induces $\mathrm{p} 27^{\mathrm{Kip1}}$-dependent cell cycle arrest and apoptosis in MCF-7 human breast cancer cells. Eur J Pharmacol 641: 29-34, 2010.

41. Lee YS, Choi KM, Choi MH, Ji SY, Lee S, Sin DM, Oh KW, Lee YM, Hong JT, Yun YP and Yoo HS: Serine palmitoyltransferase inhibitor myriocin induces growth inhibition of $\mathrm{B} 16 \mathrm{~F} 10$ melanoma cells through $\mathrm{G} 2 / \mathrm{M}$ phase arrest. Cell Prolif 44: 320-329, 2011

42. Kim KN, Ahn G, Heo SJ, Kang SM, Kang MC, Yang HM, et al: Inhibition of tumor growth in vitro and in vivo by fucoxanthin against melanoma B16F10 cells. Environ Toxicol Phar 35: 39-46, 2013.

43. Wang P, Ma Q, Luo J, Liu B, Tan F, Zhang Z and Chen Z: Nkx3.1 and $\mathrm{p} 27^{\mathrm{KIP} 1}$ cooperate in proliferation inhibition and apoptosis induction in human androgen-independent prostate cancer cells. Cancer Invest 27: 369-375, 2009.
44. Indovina P, Giorgi F, Rizzo V, Khadang B, Schenone S, Di Marzo D, Forte IM, Tomei V, Mattioli E, D'Urso V, Grilli B, Botta M, Giordano A and Pentimalli F: New pyrazolo[3,4-d] pyrimidine SRC inhibitors induce apoptosis in mesothelioma cell lines through p27 nuclear stabilization. Oncogene 31: 929-938, 2012.

45. Alesiani D, Cicconi R, Mattei M, Montesano C, Bei R and Canini A: Cell cycle arrest and differentiation induction by 5,7-dimethoxycoumarin in melanoma cell lines. Int J Oncol 32: 425-434, 2008.

46. Tabolacci C, Lentini A, Provenzano B, Gismondi A, Rossi S and Beninati S: Similar antineoplastic effects of nimesulide, a selective COX-2 inhibitor, and prostaglandin E1 on B16-F10 murine melanoma cells. Melanoma Res 20: 273-279, 2010.

47. Moleephan W, Wittayalertpanya S, Ruangrungsi N and Limpanasithikul W: Effect of xanthoxylin on melanin content and melanogenic protein expression in B16F10 melanoma. Asian Biomed 6: 413-422, 2012. 